\title{
CORROSION BEHAVIOR OF Zr-10Mo ALLOYS IN NIOBIUM-DOPED LACTATE RINGER'S SOLUTION
}

\author{
Vita Yuliana Prastika ${ }^{1}$, Pradoto Ambardi ${ }^{1}$ and Djoko Hadi Prajitno ${ }^{1,2}$ \\ ${ }^{1,2}$ Teknik Metalurgi - Universitas Jenderal Achmad Yani \\ Jl. Terusan Jenderal Gatot Subroto, Bandung, 40285 \\ ${ }^{2}$ Pusat Sains dan Teknologi Nuklir Terapan - BATAN \\ Jl. Tamansari 71, Bandung 40132 \\ E-mail: vitaaprastika@gmail.com
}

Revised: 20 June 2019

Accepted: 25 June 2019

\begin{abstract}
CORROSION BEHAVIOR OF Zr-10MO ALLOYS IN NIOBIUM-DOPED LACTATE RINGER'S SOLUTION. This research discusses the corrosion behavior of $\mathrm{Zr}-10 \mathrm{Mo}$ alloys in Niobium-doped lactate ringer's solution. The addition of Niobium of $1 \%, 3 \%$ and $5 \%$ on $\mathrm{Zr}-10 \mathrm{Mo}$ alloys aims to study the effect of adding Niobium to the hardness, microstructure and corrosion resistance of Zr-Mo alloys. The alloys are made by melting the materials of $\mathrm{Zr}$, Mo and $\mathrm{Nb}$ with a certain percentage of weight using single arc melting furnace in Argon atmosphere with high purity and Tungsten eletrodes. The alloys (as cast) are subjected to hardness testing using $\mathrm{C}$-scale rockwell, microstructure using optical microscopy, compounds and phases in the alloys (as cast) using XRD and corrosion testing using polarization method in lactate ringers' solution. The hardness value increases by the addition of Niobium, Zr-10Mo-1 Nb alloy of $34 \mathrm{HRC}, \mathrm{Zr}-10 \mathrm{Mo}-3 \mathrm{Nb}$ alloy of $38 \mathrm{HRC}$ and $\mathrm{Zr}-10 \mathrm{Mo}-5 \mathrm{Nb}$ alloy of $41.5 \mathrm{HRC}$. The basketweave-shaped microstructure with the addition of Niobium creates relatively smaller grain size. The value of corrosion rate decrases by the addition of Niobium at the immersion times of 0 minute, 60 minutes and 120 minutes, $\mathrm{Zr}-10 \mathrm{Mo}-1 \mathrm{Nb}$ alloy of $4.208 \mathrm{mpy}, \mathrm{Zr}-10 \mathrm{Mo}-3 \mathrm{Nb}$ alloy of $3.538 \mathrm{mpy}$ and $\mathrm{Zr}-10 \mathrm{Mo}-5 \mathrm{Nb}$ alloy of $2.813 \mathrm{mpy}$, included in the excellent category (1-5 mpy).
\end{abstract}

Keywords: Niobium, Zr-10Mo Alloy, Hardness, Corrosion Resistance, Lactate Ringer

\begin{abstract}
ABSTRAK
PERILAKU KOROSI PADUAN Zr-10Mo DALAM LARUTAN RINGER LAKTAT YANG DI DOPING NIOBIUM. Dalam penelitian ini dibahas mengenai perilaku korosi paduan Zr-10Mo dalam larutan ringer laktat yang di doping Niobium. Penambahan unsur Niobium antara $1 \%$, 3\% dan 5\% pada paduan Zr-10Mo bertujuan untuk mempelajari pengaruh penambahan unsur Niobium terhadap kekerasan, struktur mikro dan ketahanan korosi paduan Zr-Mo. Paduan dibuat dengan cara meleburkan material $\mathrm{Zr}$, Mo dan $\mathrm{Nb}$ dengan persentase berat tertentu menggunakan single arc melting furnace dalam atmosfer Argon dengan kemurnian tinggi dan elektroda Tungsten. Paduan (as cast) dilakukan pengujian kekerasan menggunakan rockwell skala C, struktur mikro menggunakan mikroskop optik, senyawa dan fasa pada paduan (as cast) menggunakan XRD serta pengujian korosi dengan metode polarisasi dalam larutan ringer laktat. Nilai kekerasan meningkat dengan penambahan unsur Niobium, paduan Zr-10Mo-1 Nb sebesar $34 \mathrm{HRC}$, paduan Zr-10Mo-3Nb sebesar $38 \mathrm{HRC}$ dan paduan $\mathrm{Zr}-10 \mathrm{Mo}-5 \mathrm{Nb}$ sebesar 41,5 HRC. Struktur mikro berbentuk basketweave dengan penambahan unsur Niobium ukuran butir relatif lebih kecil. Nilai laju korosi menurun dengan penambahan unsur Niobium dalam waktu imersi 0 menit, 60 menit dan 120 menit, paduan $\mathrm{Zr}$-10Mo-1Nb sebesar 4,208 mpy, paduan $\mathrm{Zr}-10 \mathrm{Mo}-3 \mathrm{Nb}$ sebesar 3,538 mpy dan paduan $\mathrm{Zr}-10 \mathrm{Mo}-5 \mathrm{Nb}$ sebesar 2,813 mpy, termasuk kategori excellent (1-5 mpy).
\end{abstract}

Kata kunci: Niobium, Paduan Zr-10Mo, Kekerasan, Ketahanan Korosi, Ringer Laktat 


\section{INTRODUCTION}

Zirconium is mainly used as a structural material in nuclear applications due to its low absorption of neutrons. Recently, zirconium-based materials have gained attention as structural materials for aerospace, chemical and biomedical applications because of their resistance against corrosion and wear [1]. The combination of acceptable strength, high corrosion resistance and good biocompatibility has made zirconium alloys suitable for biomaterials for orthopedic implants. Zirconium has been known as non-toxic and nonallergic [2]. Alloy-based $\mathrm{Zr}$ has recently been used as orthopedic biomaterials [3-5], such as artificial knee joints [3]. However, the mechanical reliability of $\mathrm{Zr}$ is not sufficient to be used as structural biomaterials. Using Mo as $\mathrm{Zr}$ alloy element because it is an effective reinforcement element for $\mathrm{Zr}[6,7]$ and this shows low cytotoxicity $[6,8]$ and low magnetic weakness [6]. Molybdenum (Mo) or Niobium ( $\mathrm{Nb}$ ) elements have been added to the Zr matrix to develop binary alloys and show a strengthening effect, low magnetic susceptibility and or low modulus [7,9-11].

$\mathrm{Zr}$ and its alloys are also known as bioactive metallic biomaterials which are very good because they can form apatite layers like bone on the surface in the body of living creatures. In general, $\mathrm{Zr}$ exhibits high mechanical strength, high toughness against fracture and good corrosion resistance, so that it can act as a structural material. As a result, $\mathrm{Zr}$ alloy is an ideal material developed for the replacement of biological hard tissues. However, to date, reports of the application of $\mathrm{Zr}$ alloys in the replacement of biological hard tissues are still very rare. The microstructure and magnetic susceptibility of Zr-Mo alloys as cast have been studied and it was found that $\mathrm{Zr}$ alloys are useful for medical devices that use Magnetic Resonance Imaging (MRI) [3, 12].

This study aims for the behavior of corrosion resistance of alloy biomaterials $\mathrm{Zr}-10 \mathrm{Mo}-\mathrm{xNb}(\mathrm{x}=1 \%$, $3 \%$ and $5 \%$ ) as-cast condition in the ringer's lactate solution by polarization method, as well as for developing orthopedic biomaterials such as artificial knee joints.

\section{EXPERIMENTAL METHOD}

\section{Materials and Instruments}

This study uses materials consisting of Zirconium sponge with $99 \%$ purity (Aldrich Chemical), Molibdenum rod with $99.8 \%$ purity (Goodfellow) and Niobium with 99.9\% purity (ESPI Metals), and ringer's lactate solution (PT. Widatra Bhakti).

The equipment used in this study consists of Mettler Toledo AL204 Analytical Scale to weigh the materials according to the composition in Table 1, single arc melting furnace of PSTNT BATAN to melt the materials into alloys, hardness rockwell scale-C Krisbow KW0600121 to obtain the hardness value of the alloy,
Table 1. Composition of alloy (in \%wt)

\begin{tabular}{ccccccc}
\hline $\begin{array}{c}\text { Alloy } \\
\text { (as cast })\end{array}$ & $\%$ & $\mathrm{Zr}$ & \multicolumn{2}{c}{ Mo } & \multicolumn{2}{c}{$\mathrm{Nb}$} \\
\hline $\mathrm{Zr}-10 \mathrm{Mo}-1 \mathrm{Nb}$ & 89 & 13.35 & 10 & 1.5 & 1 & 0.15 \\
$\mathrm{Zr}-10 \mathrm{Mo}-3 \mathrm{Nb}$ & 87 & 13.05 & 10 & 1.5 & 3 & 0.45 \\
$\mathrm{Zr}-10 \mathrm{Mo}-5 \mathrm{Nb}$ & 85 & 12.75 & 10 & 1.5 & 5 & 0.75 \\
\hline
\end{tabular}

Optical microscope Eclipse LV150 to analyize the microstructure of alloy, X-Ray Diffraction (XRD) PANalytical X'Pert PRO PW3040/x0 to analyize compounds and phases in alloy, "Gamry Framework" software to study tafel polarization and corrosion rate of corrosion test results by the polarization method referring to ASTM G59 standard, corrosion testing using the polarization method with counter electrode in the form of platinum wires, reference electrode in the form of reference electrode $\mathrm{Ag}-\mathrm{AgCl}$ Fisher ScientificTMAccumetTM, and work electrodes in the form of alloy to be tested.

\section{Method and Procedure}

The materials are weighed with the composition in Table 1 with a total weight of 15 grams per alloy, then the melting process is conducted using single arc melting furnace, the melting process uses Tungsten electrode (W) given an electric current with a voltage of $230 \mathrm{~V}$ and current of \pm 110 A so as to produce an arc that will melt the materials in a copper crucible hearth which is flowed with water as a cooler, the process is carried out in the atmosphere of Argon UHP $99.99 \%$ gas with high purity which aims to protect the melted materials from oxidizing. The melting process of each alloy is carried out 4 times to get homogeneous alloy results, melting results such as buttons. Each alloy (as cast) is prepared to form a cylindrical shape of $\pm 15 \mathrm{~mm}$ diameter and $\pm 4 \mathrm{~mm}$ thick.

Each alloy undergoes initial characterization in the form of hardness test using hardness rockwell scale$\mathrm{C}$ referring to ASTM E18 with indentation in the form of a diamond cone, minor load of $10 \mathrm{~kg}$, major load of 140 $\mathrm{kg}$ and total load of $150 \mathrm{~kg}$. Metallographic examination is conducted at the upper alloy surface, each alloy is prepared first with the sanding process using 60-2000 mesh sandpaper, polishing process uses a velvet cloth and $\mathrm{ZrO}_{2}$ polishing powder as the abrasive particle and the etching process uses etching solution with the composition of $5 \% \mathrm{H}_{2} \mathrm{SO}_{4}, 10 \% \mathrm{HF}, 30 \% \mathrm{HNO}_{3}$ and $55 \%$ $\mathrm{H}_{2} \mathrm{O}$, the etching is conducted by immersion. The initial XRD testing is conducted on the upper alloy surface, after obtaining initial characterization, each alloy is subjected to corrosion testing using the polarization method referring to ASTM G59 standard in ringer's lactate solution. This testing uses three types of electrodes namely reference electrode $(\mathrm{Ag}-\mathrm{AgCl})$, counter electrodes (platinum wire) and work electrode (alloy to be tested), the three electrodes are connected 
to the potentiostat and the computer with "Gamry Framework" software. Polarization curves are obtained in the potential range of $-350 \mathrm{mV}$ (initial) to $+350 \mathrm{mV}$ (final). Corrosion testing in ringer's lactate solution is carried out by varying the immersion time of each alloy i.e. 0 minute, 60 minutes and 120 minutes.

After corrosion testing by the polarization method, the alloy is subjected to final characterization by XRD testing.

Ringer's lactate solution is used as the corrotion medium as it resembles ion, the concentration and $\mathrm{pH}$ of human body, where the composition of ringer's lactate solution can be seen in Table 2 .

Table 2. Chemical composition of ringer's lactate solution.

\begin{tabular}{cc}
\hline Reagent & Composition $(\mathrm{g} / \mathrm{mL})$ \\
\hline Sodium Lactate $\left(\mathrm{C}_{3} \mathrm{H}_{5} \mathrm{NaO}_{3}\right)$ & $1.55 \mathrm{~g} / 500 \mathrm{~mL}$ \\
Sodium Chloride $(\mathrm{NaCl})$ & $3.0 \mathrm{~g} / 500 \mathrm{~mL}$ \\
Potassium Chloride $(\mathrm{KCl})$ & $0.15 \mathrm{~g} / 500 \mathrm{~mL}$ \\
Calcium Chloride & $0.1 \mathrm{~g} / 500 \mathrm{~mL}$ \\
$\left(\mathrm{CaCl}_{2} .2 \mathrm{H}_{2} \mathrm{O}\right)$ & \\
Water for injection & $500 \mathrm{~mL}$ \\
Osmolaritas & $274 \mathrm{mOsm} / \mathrm{L}$ \\
$\mathrm{Na}^{+}$ & $130.3 \mathrm{mEq} / \mathrm{L}$ \\
$\mathrm{K}^{+}$ & $4 \mathrm{mEq} / \mathrm{L}$ \\
Lactate $\left(\mathrm{HCO}_{3}{ }^{-}\right)$ & $27.7 \mathrm{mEq} / \mathrm{L}$ \\
$\mathrm{Cl}^{-}$ & $109.4 \mathrm{mEq} / \mathrm{L}$ \\
$\mathrm{Ca}^{++}$ & $2.7 \mathrm{mEq} / \mathrm{L}$ \\
\hline
\end{tabular}

\section{RESULTS AND DISCUSSION}

Based on the results of hardness testing using the C-scale rockwell method in Table 3, the hardness test results data on each alloy ara obtained.

Table 3. Effect of $\mathrm{Nb}$ on the hardness Vickers of Alloys.

\begin{tabular}{cc}
\hline $\begin{array}{c}\text { Alloy } \\
\text { (as cast) }\end{array}$ & $\begin{array}{c}\text { Hardness Value } \\
\text { Rockwell C (HRC) }\end{array}$ \\
\hline Zr-10Mo-1Nb & 34 \\
Zr-10Mo-3Nb & 38 \\
Zr-10Mo-5Nb & 41.5 \\
\hline
\end{tabular}

The addition of Niobium element from 0 to $9 \%$ by $\mathrm{Nb}$ weight in Zirconium-based alloys can increase the hardness value and reduce the modulus young value [13]. The addition of Niobium element of $1 \%, 3 \%$ and $5 \%$ increases the alloy hardness of Zr-10Mo-1 Nb by $34 \mathrm{HRC}$, $\mathrm{Zr}-10 \mathrm{Mo}-3 \mathrm{Nb}$ by $38 \mathrm{HRC}$ and $\mathrm{Zr}-10 \mathrm{Mo}-5 \mathrm{Nb}$ by $41.5 \mathrm{HRC}$. This is due to the addition of Molybdenum element which has a strengthening effect on Zirconium, the radius of Zirconium atom $(0.155 \mathrm{~nm})$ and Molybdenum $(0.139 \mathrm{~nm})$ shows the substitutional solid solution and has too high electronegativity difference, the electronegativity of Zirconium atom (1.33) is smaller than Molybdenum (2.16) so that it will form a second phase of Mo2Zr which has a higher hardness than pure Zirconium and the $\beta$ phase lattice parameter in the alloy decreases by increasing the Niobium element content so that internal stress occurs, and the radius of Niobium atom $(0.145 \mathrm{~nm})$ is smaller than Zirconium $(0.155 \mathrm{~nm})$ showing that substitutional solid solution occurs in the alloy.

With the increase in hardness, it is inversely proportional to the young modulus in zirconium alloys. The value of modulus young has decreased and is close to natural bone modulus young (10-30 GPa)[2], zirconium alloys show promising potential for new biomaterials from a relatively low modulus young point of view (closer to natural bone modulus young) compared to biomaterials alloy Ti-6Al-4V (107.2 GPa) and Stainless Steel $304(173.3 \mathrm{GPa})$ [2], thus Zr-10Mo-xNb alloy ( $\mathrm{x}=1 \%$, $3 \%$ and $5 \%$ ) in this study is appropriate to be used as a new implant.

The results of metallographic examination with 200x magnification can be seen in Figure 1.
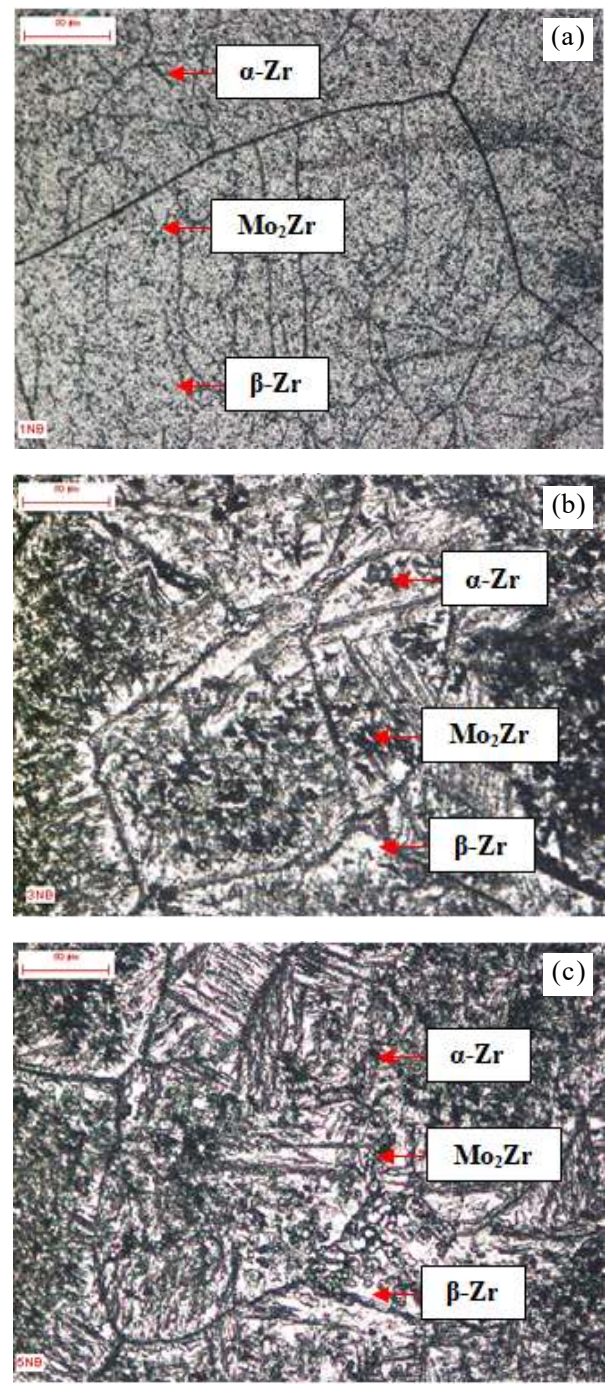

Figure 1. Microstructure of $\mathrm{Zr}-\mathrm{Mo}-\mathrm{Nb}$ alloys (a). Zr-10Mo-1Nb; (b). Zr-10Mo$3 \mathrm{Nb}$ and (c). Zr-10Mo-5Nb

The microstructure in basketweave-shaped $\mathrm{Zr}$ $10 \mathrm{Mo}, \mathrm{Zr}-10 \mathrm{Mo}-1 \mathrm{Nb}, \mathrm{Zr}-10 \mathrm{Mo}-3 \mathrm{Nb}$ and $\mathrm{Zr}-10 \mathrm{Mo}-5 \mathrm{Nb}$ alloys contain black dendritic $\alpha-Z r$ phase in the white 
$\beta-Z r$ phase $[14,16]$ and Mo2Zr intermetallic compound in the $\alpha-Z r$ phase [17]. $\alpha-Z r$ phase is black dendritic at the $\beta-\mathrm{Zr}$ grain boundary, $\alpha-\mathrm{Zr}$ phase that grows from a number of different nucleation areas in $\beta-Z r$ grain area where the form of those plates intersect and do not have time to extent forming the basketweave structure, this is because the insoluble Niobium element in $\beta-Z r$ phase serves as the nucleation site of $\alpha-Z r$ phase during the colling time with the final basketweave structure [16]. In the $\mathrm{Zr}-10 \mathrm{Mo}-\mathrm{xNb}$ alloy $(\mathrm{x}=1 \%, 3 \%$ and $5 \%)$, the transformation mechanism of $\beta-\mathrm{Zr}$ phase into $\alpha-\mathrm{Zr}$ phase + Mo2Zr intermetallic compound starts from the early cooling stage from the melting of Zirconium alloy into $\beta-\mathrm{Zr}$ phase, the next stage is the $\alpha-\mathrm{Zr}$ nuclei grow and are trapped in the $\beta-Z r$ grain and Mo2Zr intermetallic compound grows in the $\alpha-Z r$ phase.

With the addition of higher Niobium, it will cause more nuclei centers so as to refine the grain size into relatively smaller size [14]. In Figure 1, it appears that the grain size and relatively small grain size refinement occur by the addition of higher Niobium, as Niobium serves as a nucleating agent.

$\mathrm{Zr}-10 \mathrm{Mo}-5 \mathrm{Nb}$ alloy has smaller grain size compared to $\mathrm{Zr}-10 \mathrm{Mo}-1 \mathrm{Nb}$ and $\mathrm{Zr}-10 \mathrm{Mo}-3 \mathrm{Nb}$ alloys, so $\mathrm{Zr}-10 \mathrm{Mo}-5 \mathrm{Nb}$ alloy has higher hardness value, as the $5 \%$ content of Niobium element results in more nucleation centers compared to the Niobium element with less than $5 \%$ content in $\mathrm{Zr}-10 \mathrm{Mo}-\mathrm{xNb}$ alloy. Therefore, it is known that the smaller the grain sizes in the alloy microstructure, the higher the alloy hardness. This is in accordance with Hall-Petch equation [15], as follows:

$$
\sigma y=\sigma i+k / \sqrt{ } d
$$

where:

$$
\begin{aligned}
& \sigma \mathrm{y}=\text { Material yield stress } \\
& \sigma \mathrm{i}=\text { The stress needed to move the dislocation } \\
& \mathrm{k}=\text { Constant } \\
& \mathrm{d}=\text { Grain size }
\end{aligned}
$$

Based on the results of corrosion testing with the polarization method, the tafel polarization curve is obtained in Figure 2.

Table 4. Data of constant Tafel, corrosion potential and corrosion rate with different immersion time. Niobium is one of betha stabilizers or beta stabilizer element for zirconium alloys, $\beta$ phase has better corrosion resistance compared to $\alpha$ phase, in this study the addition of Niobium element in $\mathrm{Zr}$-10Mo binary alloy is conducted as it can stabilize and increase $\beta$ phase, so the addition of Niobium element by $1 \%, 3 \%$ and $5 \%$ can increase corrosion resistance, Niobium element is also more reactive to form a passive layer compared to Molybdenum element (18).

Based on the curve of the effect of Niobium on the corrosion rate, it shows that the addition of higher Niobium $(\mathrm{Nb}=1 \%, 3 \%$ dan $5 \%)$ in $\mathrm{Zr}-10 \mathrm{Mo}-\mathrm{xNb}$ alloy
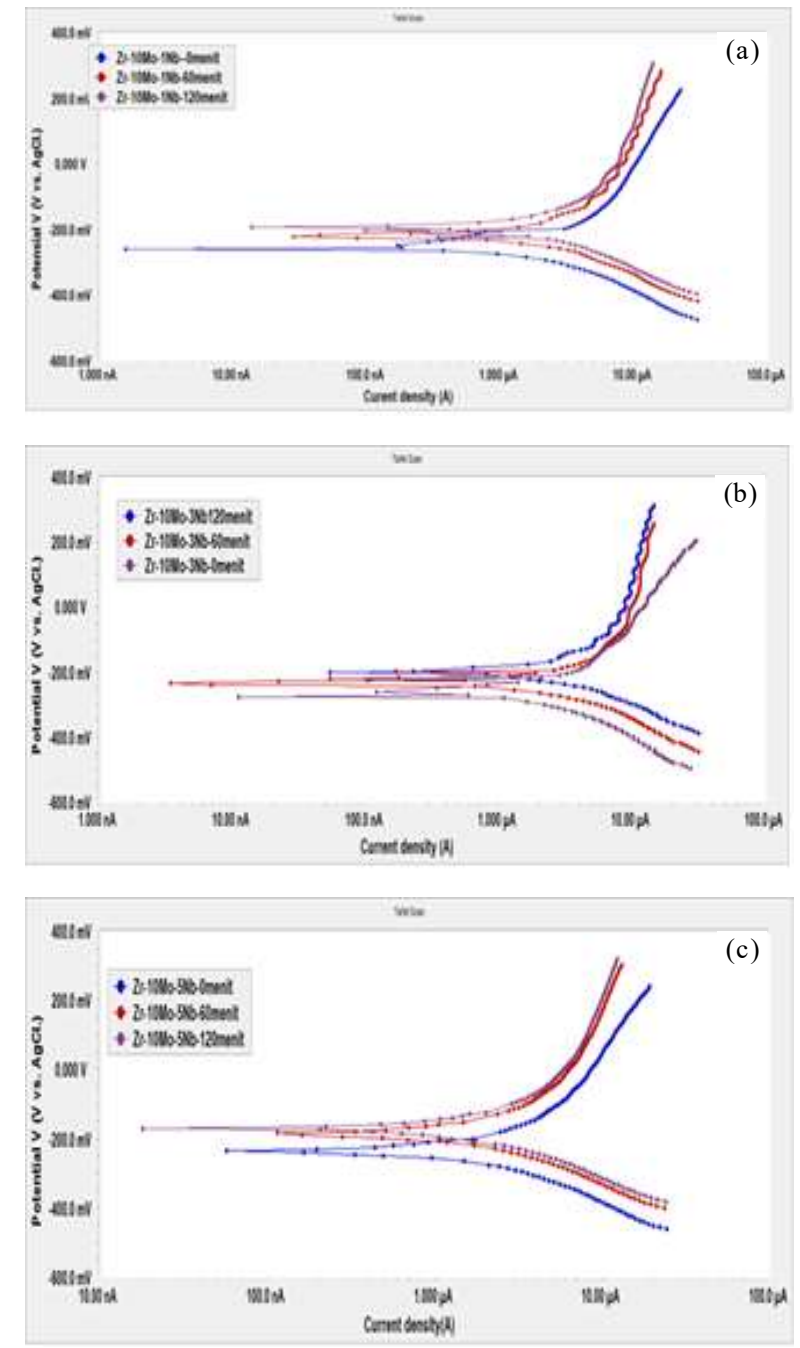

Figure 2. Tafel polarization curve of $\mathrm{Zr}-\mathrm{Mo}-\mathrm{Nb}$ alloys. (a). $\mathrm{Zr}-10 \mathrm{Mo}-1 \mathrm{Nb}$; (b). $\mathrm{Zr}-10 \mathrm{Mo}-3 \mathrm{Nb}$ and (c). $\mathrm{Zr}-10 \mathrm{Mo}-5 \mathrm{Nb}$

Table 4. shows the results of processing the tafel polarization curve for each alloy.

\begin{tabular}{ccccc}
\hline \multirow{2}{*}{$\begin{array}{c}\text { Alloy } \\
\text { (as cast) }\end{array}$} & Remark & \multicolumn{3}{c}{ Immersion time } \\
& & 0 mins & 60 mins & 120 mins \\
\hline \multirow{3}{*}{$\mathrm{Zr}-10 \mathrm{Mo}-1 \mathrm{Nb}$} & $\mathrm{I}_{\text {corr }}(\mu \mathrm{A})$ & 4.339 & 4.009 & 4.640 \\
& $\mathrm{E}_{\text {corr }}(\mathrm{mV})$ & -256.4 & -216.6 & -194.0 \\
& Corrosion rate $(\mathrm{mpy})$ & 4.790 & 4.426 & 4.208 \\
\hline \multirow{3}{*}{$\mathrm{Zr}-10 \mathrm{Mo}-3 \mathrm{Nb}$} & $\mathrm{I}_{\text {corr }}(\mu \mathrm{A})$ & 5.250 & 3.950 & 3.910 \\
& $\mathrm{E}_{\text {corr }}(\mathrm{mV})$ & -259.0 & -220.0 & -201.0 \\
& Corrosion rate $(\mathrm{mpy})$ & 4.757 & 3.578 & 3.538 \\
\hline \multirow{2}{*}{$\mathrm{Zr}-10 \mathrm{Mo}-5 \mathrm{Nb}$} & $\mathrm{I}_{\text {corr }}(\mu \mathrm{A})$ & 3.780 & 3.370 & 3.100 \\
& $\mathrm{E}_{\text {corr }}(\mathrm{mV})$ & -235.0 & -186.0 & -170.0 \\
& Corrosion rate $(\mathrm{mpy})$ & 3.429 & 3.053 & 2.813 \\
\hline
\end{tabular}

results in a lower corrosion rate so that corrosion resistance increases. The corrosion rate in $\mathrm{Zr}-10 \mathrm{Mo}-1 \mathrm{Nb}$ alloy of $4.208 \mathrm{mpy}, \mathrm{Zr}-10 \mathrm{Mo}-3 \mathrm{Nb}$ alloy of $3.538 \mathrm{mpy}$ and $\mathrm{Zr}-10 \mathrm{Mo}-5 \mathrm{Nb}$ alloy of 2.813 mpy can be seen in Table 4 , the decrease in the corrosion rate produced is in the range 1-5 mpy and included in the excellent category, the addition of Niobium tends to increase more $\beta$ phase, thereby increasing the corrosion 


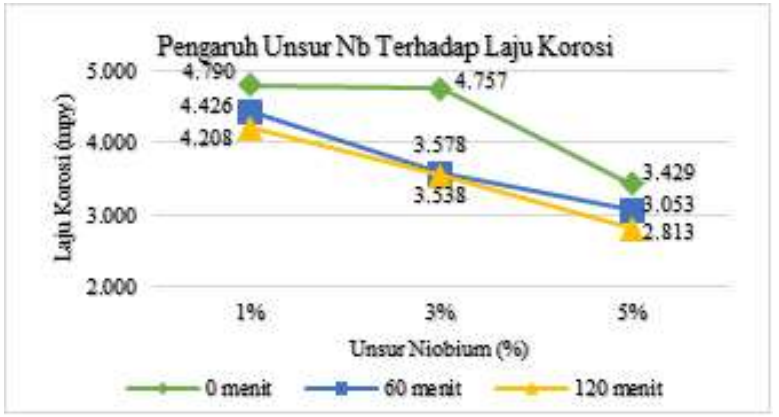

Figure 3. Effect of Niobium on the corrosion rate.

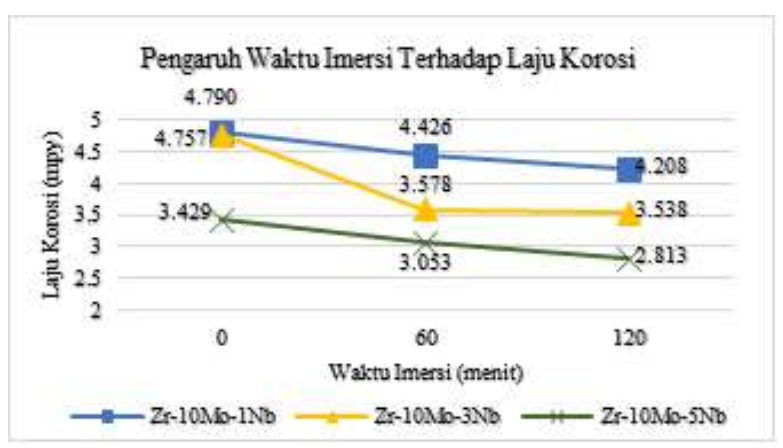

Figure 4. Effect of immersion time on the corrosion rate.

resistance of $\mathrm{Zr}-10 \mathrm{Mo}-\mathrm{xNb}$ alloy $(\mathrm{x}=1 \%, 3 \%$ and $5 \%)$, this is proven by the decreased corrosion rate and the formation of a stable $\mathrm{ZrO}_{2}$ passive layer and $\mathrm{NbO}_{2}$ passive layer.

The more addition of Niobium in the alloy and the longer the immersion time causes the corrosion potential to increase in the positive direction and the corrosion current decreases, so that the corrosion rate decreases due to the formation of a more stable passive layer and has better corrosion resistance.

Based on the curve of the effect of immersion time on the corrosion rate, it shows that an immersion time of 0 minute, 60 minutes and 120 minutes decreases the corrosion rate, this is due to the formation of $\mathrm{ZrO}_{2}$ and $\mathrm{NbO}_{2}$ passive layers which are more stable in longer immersion time, $\mathrm{Zr}-10 \mathrm{Mo}-1 \mathrm{Nb}$ alloy during immersion time of 0 minute has a corrosion rate of 4.790 mpy, immersion time of 60 minutes has a corrosion rate of $4.426 \mathrm{mpy}$ and 120 minutes has a corrosion rate of $4.208 \mathrm{mpy}, \mathrm{Zr}-10 \mathrm{Mo}-3 \mathrm{Nb}$ alloy during 0 -minute immersion time has a corrosion rate of $4.757 \mathrm{mpy}$, immersion time of 60 minutes has a corrosion rate of 3.579 mpy and 120 minutes has a corrosion rate of $3.538 \mathrm{mpy}$ and $\mathrm{Zr}-10 \mathrm{Mo}-5 \mathrm{Nb}$ alloy during 0 -minute immersion time has a corrosion rate of $3.429 \mathrm{mpy}$, immersion time of 60 minutes has a corrosion rate of 3.053 mpy and 120 minutes has a corrosion rate of $2.813 \mathrm{mpy}$, the decrease in corrosion rate produced with an immersion time of 0 minute, 60 minutes and 120 minutes is in the range of 1-5 mpy and categorized as excellent.

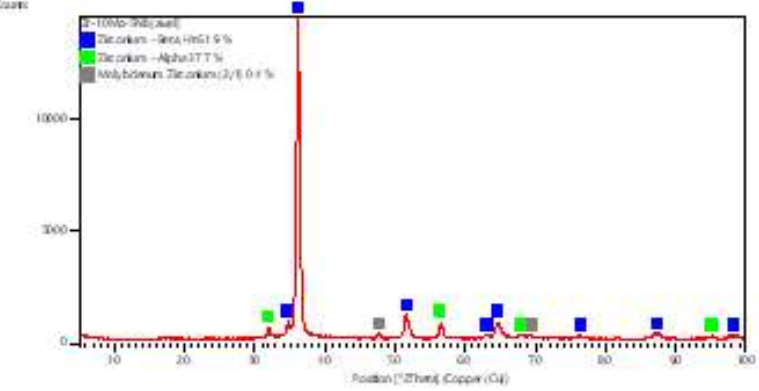

Figure 5. XRD pattern of $\mathrm{Zr}-10 \mathrm{Mo}-5 \mathrm{Nb}$ alloy before corrosion testing.

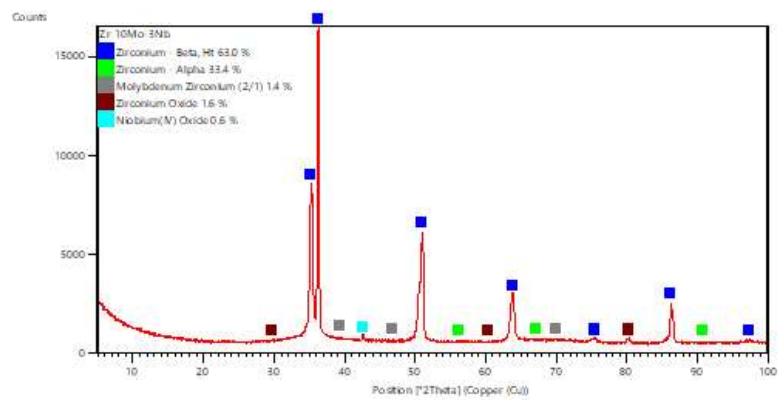

Figure 6. XRD pattern of $\mathrm{Zr}-10 \mathrm{Mo}-3 \mathrm{Nb}$ alloy after corrosion testing.

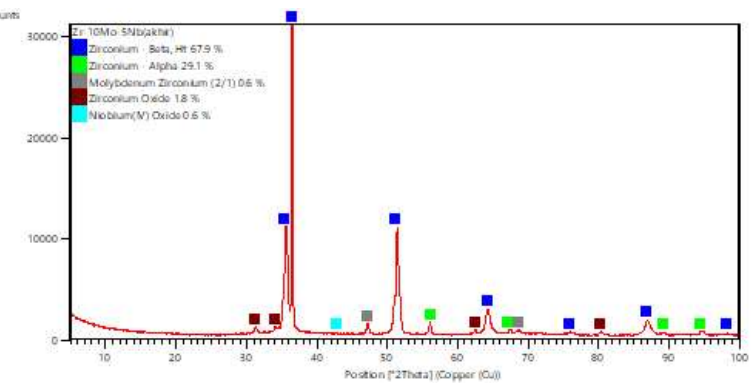

Figure 7. XRD pattern of $\mathrm{Zr}-10 \mathrm{Mo}-5 \mathrm{Nb}$ alloy after corrosion testing.

In Figures 5 to 7, the XRD pattern of the alloy (as cast) before and after corrosion testing by the polarization method is obtained.

Based on the XRD patterns it can be seen that the phases formed in $\mathrm{Zr}-10 \mathrm{Mo}-3 \mathrm{Nb}$ and $\mathrm{Zr}-10 \mathrm{Mo}-5 \mathrm{Nb}$ alloys are $\alpha-Z r$ phase, $\beta-Z r$ phase and Mo2Zr intermetallic compound. The highest peak is by $\beta-\mathrm{Zr}$ phase, while $\alpha-Z r$ phase and Mo2Zr intermetallic compound have a lower peak, this shows that the intensity of $\beta$-Zr phase is higher than $\alpha$-Zr phase and Mo2Zr intermetallic compound. After corrosion testing with the polarization method on the alloys, $\mathrm{ZrO}_{2}$ oxide compound and $\mathrm{NbO}_{2}$ oxide compound are formed as passive layers.

$\mathrm{Zr}-10 \mathrm{Mo}-5 \mathrm{Nb}$ alloys has lower corrosion rate compared to $\mathrm{Zr}-10 \mathrm{Mo}-3 \mathrm{Nb}$, this is proven by the formation of more $\mathrm{ZrO}_{2}$ oxide compound than $\mathrm{NbO}_{2}$ oxide compound in $\mathrm{Zr}-10 \mathrm{Mo}-3 \mathrm{Nb}$ alloy in XRD patterns. The number of $\mathrm{ZrO}_{2}$ oxide compound is greater than $\mathrm{NbO}_{2}$, this is because Zirconium has a lower Eosel $($ Eosel $=-1.45)$ compared to Niobium $($ Eosel $=-1.099)$, so 
Zirconium is more reactive and more easily oxidized compared to Niobium, whereas Molybdenum is less reactive to form Mo-oxide compound than Zirconium and Niobium because it has a higher Eosel (Eosel= -0.2), it takes longer immersion time to form Mo-oxide compound. The reaction of the formation of a passive layer is as follows:

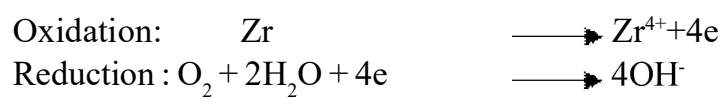

\begin{tabular}{lll}
\hline Total reaction & $: \mathrm{Zr}+\mathrm{O}_{2}+2 \mathrm{H}_{2} \mathrm{O}$ & $\mathrm{Zr}(\mathrm{OH})_{4}$ \\
$\mathrm{Zr}(\mathrm{OH})_{4}$ & $\mathrm{ZrO}_{2}+2 \mathrm{H}_{2} \mathrm{O}$
\end{tabular}

$\begin{array}{ll}\text { Oxidation: } \quad \mathrm{Nb} & \longrightarrow \mathrm{Nb}^{4+}+4 \mathrm{e} \\ \text { Reduction }: \mathrm{O}_{2}+2 \mathrm{H}_{2} \mathrm{O}+4 \mathrm{e} & \longrightarrow \mathrm{OH}^{-}\end{array}$

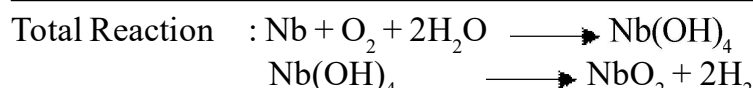

In the presence of $\mathrm{ZrO}_{2}$ oxide compound and $\mathrm{NbO}_{2}$ oxide compound which are passive, the alloys will have better corrosion resistance compared to single $\mathrm{ZrO}_{2}$ oxide compound.

\section{CONCLUSION}

From the results of the discussion, it can be concluded as follows: Addition of Niobium $(\mathrm{Nb}=1 \%, 3 \%$ and $5 \%)$ in $\mathrm{Zr}-10 \mathrm{Mo}$ alloy increase hardness, $\mathrm{Zr}-10 \mathrm{Mo}-1 \mathrm{Nb}$ alloy has hardness of $34 \mathrm{HRC}$; $\mathrm{Zr}-10 \mathrm{Mo}-3 \mathrm{Nb}$ alloy has hardness of $38 \mathrm{HRC}$ and $\mathrm{Zr}-10 \mathrm{Mo}-5 \mathrm{Nb}$ alloys has hardness of $41.5 \mathrm{HRC}$, and the addition of Niobium decreases the corrosion rate and increase corrosion resistance, corrosion rate of $\mathrm{Zr}-10 \mathrm{Mo}-1 \mathrm{Nb}$ alloy is $4.208 \mathrm{mpy}, \mathrm{Zr}-10 \mathrm{Mo}-3 \mathrm{Nb}$ alloy is $3.538 \mathrm{mpy}$ and $\mathrm{Zr}-10 \mathrm{Mo}-5 \mathrm{Nb}$ alloy is $2.813 \mathrm{mpy}$. Increased immersion time of 0 minute, 60 minutes and 120 minutes increases corrosion resistance and decreases corrosion rate in $\mathrm{Zr}-10 \mathrm{Mo}-\mathrm{xNb}$ alloy $(x=1 \%, 3 \%$ and $5 \%)$, this is due to the formation of more stable $\mathrm{ZrO}_{2}$ and $\mathrm{NbO}_{2}$ passive layers. The results of corrosion testing with the polarization method on $\mathrm{Zr}-10 \mathrm{Mo}-\mathrm{xNb}$ alloy $(\mathrm{x}=1 \%, 3 \%$ and $5 \%)$ have a corrosion rate in the range of 1-5 mpy with excellent category. Initial $\mathrm{XRD}$ test results on $\mathrm{Zr}-10 \mathrm{Mo}-5 \mathrm{Nb}$ alloy before corrosion testing contain $\alpha-\mathrm{Zr}$ phase, $\beta-\mathrm{Zr}$ phase and $\mathrm{Mo}_{2} \mathrm{Zr}$ intermetallic compounds, while the final XRD test results on $\mathrm{Zr}-10 \mathrm{Mo}-3 \mathrm{Nb}$ and $\mathrm{Zr}-10 \mathrm{Mo}-5 \mathrm{Nb}$ alloys after corrosion testing contiain $\alpha-\mathrm{Zr}$ phase, $\beta-\mathrm{Zr}$ phase, $\mathrm{Mo}_{2} \mathrm{Zr}$ intermetallic compound, $\mathrm{ZrO}_{2}$ and $\mathrm{NbO}_{2}$ oxide compounds. The formation of $\mathrm{ZrO}_{2}$ and $\mathrm{NbO}_{2}$ passive layers increases corrosion resistance in alloys.

\section{ACKNOWLEDGEMENT}

The author would like to thank PSTNT-BATAN, who provided materials for the research, synthesis and corrosion testing, as well as the Laboratory of Production Engineering-Metallurgical Engineering UNJANI who assisted the author in completing this study.

\section{REFERENCES}

[1]. R. Chelariu, et al. "Corrosion behavior of new quaternary ZrNbTiAl alloys in simulated physiological solution using electrochemical techniques and surface analysis methods". J Electrochimica Acta, vol. 248, pp. 368-375, Jul. 2017.

[2]. F.Y. Zhou, et al. "Microstructure, mechanical property, corrosion behavior, and in vitro biocompatibility of $\mathrm{Zr}-\mathrm{Mo}$ alloys". J Biomedical Material Research, part B, pp. 237-246, 2013.

[3]. Suyalatu, et al. "Microstructure And Magnetic Susceptibility of as-Cast Zr-Mo Alloys". J Acta Biomaterialia, vol. 6, Issue 3, pp. 1033-1038, 2010.ganr

[4]. Sah AP, Ready JE. "Use of oxidized zirconium hemiarthroplasty in hip fractures". J Arthroplasty, vol. 22,pp. 1174-80, 2007.

[5]. Ries MD, Saheli A, Widding K, Hunter G. "Polyethylene wear performance of oxidized zirconium and cobalt-chromium knee components under abrasive conditions". J Bone Joint Surg Am, vol. 84, pp. 129-135, 2002.

[6]. Suyalatu, et al. "Effects of Phase Constitution on Magnetic Susceptibility and Mechanical Properties of Zr-Rich Zr-Mo Alloys", J Acta Biomaterialia, vol. 7, Issue 12, pp. 4259-4266. 2011.

[7]. Northwood DO. "Heat treatment, transformation reactions and mechanical properties of two high strength zirconium alloys". J Less-Common Metals, vol. 61,pp. 199-212. 1978.

[8]. Yamamoto A, Homma R, Sumita M. "Cytotoxicity evaluation of 43 metal salts using murine fibroblasts and osteoblastic cells". J Biomedical Material Research, vol. 39, pp. 331-340. 1998.

[9]. Liang, J.S., et al. "Compositional Screening of ZrNb-Mo Alloys with CALPHAD Type Model for Promising Bio-medical Implants". CALPHAD: Computer Coupling of Phase and Thermochemistry, vol. 56,pp. 196-206. 2017.

[10]. F.Y. Zhou, et al. "Microstructure, corrosion behavior and cytotoxicity of $\mathrm{Zr}-\mathrm{Nb}$ alloys for biomedical application", J Material Science Engineering: C. 32,pp. 851-857. 2012.

[11]. R. Tewari, D. Srivastava, G.K. Dey, J.K. Chakravarty, S. Banerjee. "Microstructural evolution in zirconium based alloys", J Nuclear Material, vol. 383,pp. 153-171.2008.

[12]. Li Nie, et al. "Novel $\beta$-type $Z r-M o-T i$ alloys for biological hard tissue replacements". J Material and Design, vol. 53, pp. 8-12. 2014.

[13]. R. Kondo, N. Nomura, Suyalatu, Y. Tsutsumi, H. Doi, and T. Hanawa, "Microstructure and 
Mechanical Properties of As-Cast Zr-Nb Alloys," Acta Biomater., vol. 7, no. 12, pp. 4278-4284, 2011.

[14]. H. L. Yang et al., "Effect of molybdenum on microstructures in $\mathrm{Zr}-1.2 \mathrm{Nb}$ alloys after $\beta$ quenching and subsequently $873 \mathrm{~K}$ annealing," Mater. Des., vol. 104, pp. 355-364, 2016.

[15]. Agrawal. B. K, "Introduction to Engineering Materials," Tata McGraw-Hill, pp. 55-61, 2000.

[16]. Perdana Immanuel, Pradoto Ambardi, Djoko Hadi Prajitno,Ketahanan Oksidasi Zirkaloy-4 yang
Dipadu dengan Yttrium Pada Suhu Tinggi, Vol 25, No 1 Hal. 1-8 2019, https://doi.org/10.17146/ urania.2019.25.1.4663

[17]. W. Chubb, "High Strength Zirconium Alloy: Zr-4 Wt Pct Sn-1.6 Wt Pct Mo. Journal of Metals, pp. 461-468, 1957.

[18]. C. Vazquez, A. M. Fortis, P. B. Bozzano, Comparison of mechanical properties of $\mathrm{Zr}-1 \% \mathrm{Nb}$ and $\mathrm{Zr}-2.5 \%$ $\mathrm{Nb}$ alloys, Procedia Materials Science, 8: pp.478485,2015

Copyright (C) 2019 Jusami | Indonesian Journal of Materials Science. This article is an open access article distributed under the terms and conditions of the Creative Commons Attribution-NonCommercial-ShareAlike 4.0 International License (CC BY-NC-SA 4.0). 